Sign Systems Studies 49(3/4), 2021, 418-436

\title{
Culturally significant symbolic faces: For a sociosemiotics of faces in films
}

\author{
Antonio Santangelo ${ }^{1}$
}

\begin{abstract}
Every now and then when watching a movie, we come across faces in which we recognize a significant value, because they represent some important cultural models we use to assign meaning to our experience of the world. By way of example, I will discuss the faces of the protagonists of two recent films, Abdellatif Kechiche's La vie d'Adèle. Chapitres 1 \& 2 (2013; English title Blue Is the Warmest Colour) and Léonor Sérraille's Jeune femme (2017), comparing them with the faces of the protagonists of some older movies, such as Andrew Adamson and Vicky Jenson's Shrek (2001) and James Cameron's Avatar (2009). I will argue that the way in which the faces are portrayed is similar to the narrative structure of the stories of the characters they belong to, and that the signs and narrative structures used to construct the discourses about the world in those films are at the same time similar to those of two important cultural models of what it means to be young men and women in our times. As these cultural models are different, yet interconnected, I will argue that the most meaningful faces in cinema change due to the transformation of the cultural models they derive from and that a sociosemiotic method based on a structuralist vision of culture can help identify the most culturally significant symbolic faces on screen, and elsewhere.
\end{abstract}

Keywords: sociosemiotics; cultural models; narrative structures; structuralism; symbolic faces

\section{The faces of those who do not find meaning in our society}

This article deals with developments in a research study which started in 2017 and has already led to the publication of Santangelo 2017 and Santangelo 2021. It is based on the idea that there are images of faces that take on great symbolic value in a specific historical period, because their meaning depends on certain cultural models that define what it entails to be men or women in that time, compared to

1 Department of Philosophy and Education Science, University of Turin (Unito), Italy; e-mail: antonio.santangelo@unito.it. 
other cultural models which are embodied symbolically by different faces. Roland Barthes had already noticed this in his analysis of today's "myths", as he focused on the contrast between the faces of Greta Garbo and Audrey Hepburn in films that circulated in the 1950s. According to the French semiologist, the images of these two actresses admirably represent the moment in which cinema was about to extract an existential beauty from an essential one (Barthes 1994[1957]: 64).

Just like Barthes, in this article I intend to consider the meaning of some cinematic faces that embody cultural models relevant in contemporary society. These are the faces of the leading actresses of the films La vie d'Adele: Chapitres 1 \& 2 (Kechiche 2013; English title Blue Is the Warmest Colour) and Jeune femme (Sérraille 2017). I wish to demonstrate that the way the shots of their close-ups are constructed - with a very mobile hand-held camera, frantically searching for the focus of the image, finding it in the sensory organs of the two girls, with their eyes, noses and mouths that "experience" the colour, smell and taste of the world, while not being integrated visually into the surrounding context - resembles the overall narrative structure of the stories of Adèle and Paula, the characters played by Adèle Exarcopoulos and Laetitia Dosch. This narrative structure has been recognized by the interpreters of these films as fundamental to understanding the meaning of our lives today. This is why I wish to speak of culturally significant symbolic faces, following a tradition in the field of film studies that, according to Casetti (1994: 28-32), stretches from Aristarco (1951) to Lukács (1963), authors who argue that the so-called 'impression of reality' (Rastier 1986) elicited by a literary or cinematic fictional text depends - among other things, but, in my view and in the view of other scholars (Ferraro 2017; Gibson 2017), to a great extent ${ }^{2}$ - on its narrative structure and on the way in which this narrative structure articulates the particular types of signs that the text itself uses.

To support the claim, I need to pursue another objective as well, namely, highlighting the characteristics of the sociosemiotic method on which the claim itself is based. Contrary to Barthes, who had not considered it important to demonstrate that his interpretation of the symbolic value of the faces of Greta Garbo and Audrey Hepburn was in some way generalizable among the viewers of the films in which the actresses appear, I believe it is essential to underline the functioning of cultural models that, right from the start, manifest themselves as codes of interpretation that do not belong only to me as a semiologist, but to

2 Enunciation logics are equally important, but will not be the focus of my argument. What interests me here is understanding why the discourses on reality in a work of admittedly fictional nature appear as truthful to their recipients as those in a factual newspaper article or in a philosophical essay. It is in relation to this issue that their narrative structure proves to be more important than their enunciation mechanisms. 
a whole "community" of people who share the same vision of things. My task, therefore, is to describe the mechanisms of signification of some works and some images of faces that take on a symbolic value in a precise cultural context. To do this, I will start from the interpretations of La vie d'Adèle: Chapitres 1 \& 2 and Jeune femme that have been offered by some Italian film critics ${ }^{3}$, showing the regularities behind their apparent differences. My belief is that the former are the fruit of some codes of collective value - the cultural models I have written about so far - which serve as matrixes to give rise to some of the discourses on what it means to be young today that circulate in our society.

Finally, to show how these cultural models work, and since the sociosemiotic method that I will talk about in this article derives from structuralism and is thus focused on finding similarities starting from differences, I too, like Barthes, will refer to faces appearing in other movies. More precisely, I will work on Shrek (Adamson, Jenson 2001) and Avatar (Cameron 2009). I will show that the faces of the main characters of the later films come from another cultural model of what it means to be a young man and woman. This will allow me to zoom in on the symbolic value of the faces of Adèle and Paula. If the two girls are unable to integrate themselves into, and find meaning in, our world, the other movies tell of individuals who do become integrated but always find themselves in an "elsewhere".

I will therefore advance a hypothesis similar to the research tradition that, in the type of sociosemiotics I am interested in addressing (Fabbri 1973; Prieto 1975; Landowski 1989; Ferraro 2001, 2015; Marrone 2001; Santangelo 2012), can be traced back to Claude Lévi-Strauss (1964); that is to say that culture itself, in some respects, has its own structure and the transformations in the way of talking about reality that derive from it can be explained, at least retrospectively. What seems evident and significant to me is that much has progressively changed compared to the times when Propp (1928) identified a common constructive model and characters in the tales of Russian folklore, who were always motivated to integrate themselves into the "here", that is, into the system of values of their own society of origin, and at the end of their adventures, that often occurred in distant places, became "transfigured", assuming the features of the most representative men and women among those who populated the world to which they themselves belonged. The cultural models that give rise to our stories, as well as the symbolic faces of our age, are decidedly different: a fact that may even appear worrying, in some ways.

3 I used the key phrases 'Montparnasse femminile singolare reviews' (Montparnasse. Femminile singolare is the title that was given to Jeune Femme for its distribution in Italy) and ' $\mathrm{La}$ vita di Adele reviews' as search terms on Google, and then proceeded from the contents of the first ten links that appeared. 


\section{Stories of wanderers}

La vie d'Adèle: Chapitres 1 \& 2 is a film by Abdellatif Kechiche, winner of the Palme d'Or at the Cannes Film Festival in 2013. In Italy, some critics have written about the film's protagonist that, "exaggerating Flaubert, Adèle c'est nous", since this young woman represents the "underlying problem of the solitude of the contemporary individual, of the misery of the proposals for liberation and full and profound self-affirmation that this era makes available"5. As concerns Paula, the heroine of Jeune femme (recipient of the Un Certain Regard prize to the director and screenwriter Léonor Serraille at the Cannes Film Festival in 2017), other Italian film critics have argued that "she is really one of the most authentic female characters of recent years", "as she symbolizes the cry of the new generations who want to reclaim their place in the world" and "she is a matrix on which one could place a face extracted at random from the lot of contemporary European youth" ${ }^{\text {. }}$

As it is easy to see, the authors of these reviews seem to agree that the films are very realistic in describing contemporaneity and that their protagonists resemble all of us, or at least all the young people today. The reason for this is that both films are about two girls who are, in a sense, wanderers. Adèle and Paula, in fact, are represented while they are trying to become adults and find their own place in society and their own personal fulfillment, but it seems that they do not really know what they want and are simply trying to understand whether they like being in one way or in another. They experiment on their own skin with the various possibilities offered by the contexts in which they live, without ever finding their true being. The two young women continuously and without stopping move between heterosexual and homosexual relationships, humble and more prestigious jobs, upper-class and petit-bourgeois apartments, relatives, friends, colleagues and lovers from very different social backgrounds, in search of a sense of existence which seems to elude them.

4 Federico Pedroni, www.cineforum.it/recensione/Melodramma_materialista (last accessed 20 February 2017).

5 Goffredo Fofi, www.foglianuova.wordpress.com/2013/10/27/goffredo-fofi-la-vita-di-Adèle/ (last accessed 20 February 2017).

6 Linda Magnoni, www.cineforum.it/recensione/Montparnasse-Femminile-singolare (last accessed 25 August 2020).

7 Rolando Cisternino, www.anonimacinefili.it/2018/10/03/montparnasse-femminile-singolare/ (last accessed 25 August 2020).

8 Rudi Capra, www.ondacinema.it/film/recensione/montparnasse-femminile-singolare.html (last accessed 25 August 2020). 
In this regard, someone writes about the protagonist of Jeune Femme that "undecided about her means, her affections, her ambitions, Paula is the mirror of a generation that no longer identifies itself with the bourgeois ideals and aspirations of the second half of the twentieth century [...], yet is too weak to propose an

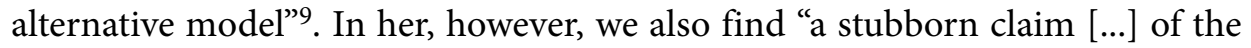
individual and personalizing factor, in a world that has reduced almost to zero the possibilities of the unexpected, entrenching itself in a system of perfect gears. Paula's inadequacy is in fact the bearer of an adequacy of another type. That of openness to others, the great missing element in these gloomy, mechanical times"10. Her story, after all, begins in diametrically opposite circumstances when her fiancé, a highly placed artist who is much older and more cultured than her, closes the door in her face and throws her out of the house, without us knowing the reasons why (later on we will understand that the two were too different and that he, while portraying her in his works, could do nothing but observe and desire her as if she were an object). The girl violently hits her head against the door trying regain access, and wounds herself in the process, but to no avail.

So begins Paula's long peregrination through Paris in search of her own existential niche, among the sofas in rich strangers' houses, in filthy hotel rooms, old attics, the humble beds of colleagues in love with her, her mother's house. In all these places, and even more in the various work environments she enters, Paula meets various people, who live according to the "mechanisms", the social rules of which the film reviews speak, and who propose that she become part of their world, adapting herself to its logic. The heroine of Jeune Femme lives through and experiences everything, following a narrative trajectory reminiscent of the flâneries of the French Nouvelle Vague cinema, but there is a major difference, immediately perceived by contemporary critics, who stress that, "compared to the films of the young Turks, Séraille's is the result of a script that is more written and less free, as well as of a vision of the world in which the bewilderment of the protagonist and her feeling lost in the non-sense of everyday life is not a declaration of anarchy with respect to the rules but a way to become part of them"11.

The problem is that, in spite of her good will, Paula is absolutely unable to integrate, so much so that her "adventures" come to an end, if one can say so, with her abandoning her home and the work she has labouriously found. We first see

9 Rudi Capra, http://www.ondacinema.it/film/recensione/montparnasse-femminile-singolare. html (last accessed 25 August 2020).

10 Massimiliano Schiavoni, https://quinlan.it/2018/05/27/montparnasse-femminile-singolare/ (last accessed 25 August 2020).

11 Carlo Cerofolini, http://icinemaniaci.blogspot.com/2018/04/Montparnasse-femminilesingolare.html (last accessed 25 August 2020). 
her walking alone along an anonymous street, after the equally solitary decision to have an abortion, thus giving up the child conceived with a colleague with whom she evidently does not wish to share her existence. Finally, we look at her as she closes the window of the attic she is leaving, surrounded by the walls that have kept her "trapped" in the asphyxiating mechanisms of a society in which, despite trying with all her might, she has not been able to "find a home"; in front of her, however, she no longer has a door barred by others against which she could slam her head, but a transparent pane of glass which she closes herself, through which she can look out and on which she playfully blows, making it steam up.

A similar open ending links Jeune Femme to La vie d'Adèle: Chapitres 1 \& 2. Already the title of the film makes it clear that it tells of an unfinished part of a life in progress. Adèle, too, is abruptly sent away from home by her partner, having been caught cheating on her with a man. It is evident that the two girls, who meet when very young and fall madly in love, subsequently grow apart as they get older, due also to the differences in their respective social backgrounds and education.

In the "first chapter" of her life a teenage Adèle, daughter of petit-bourgeois parents from the suburbs of Lille, thinks she can break all the rules, giving free rein to her passion for the slightly older Emma who comes from a more affluent family and is enrolled at the Academy of Fine Arts. Leaving Thomas, one of her most attractive schoolmates much desired by her friends, Adèle devotes herself completely to her partner, heedless of other people's opinions. She goes to live with her, supporting her and letting herself be portrayed in some paintings full of sensuality, but in spite of everything she eventually disappoints her partner with her decision to become a kindergarten teacher and discontinue her studies. In the end, Emma begins to neglect her, as they do not share the same existential horizons, and Adèle is unfaithful to her with a colleague whom she feels to be more similar.

Subsequently, however, Adèle regrets the breakup and in the "second chapter" of her life she tries to be reconciled with Emma in every possible way, until she goes to the vernissage of Emma's first solo exhibition. There all the paintings that represent her are displayed on the walls, painful memories of a time gone forever. Emma is now with another woman who is also part of the art scene. Adèle understands that there is no way back and ends up going away on her own. Like Paula at the end of Jeune Femme, we see her walking along an anonymous street in her city, not knowing where to turn.

Even in the case of this film, the Italian film critics stress the protagonist's great openness, her desire to experience life without prejudice almost as if the story told by Kechiche were superimposable on that told by Sérraille. At the same time, they highlight the castrating nature of the frequently unjust social mechanisms that 
cause suffering to today's young people: those who, like Adèle, seek their own way freely, outside the socio-cultural context from which they originate, find themselves "wandering" among very different parts of the world, in which it is not possible to settle definitively. We are encouraged to empathize with Adéle's life, invited to probe her dreams, desires and uncertainties, because "existence comes before essence; that is, experience is not made comprehensible by a previous definition of the self, but on the contrary, subjectivity is determined by the multiplicity of experiences themselves" 12 . And yet, despite this attempt not to be defined a priori by the rules of society, for several critics Adèle ends up experimenting with the "misery of the proposals for liberation and full and profound self-assertion that this era makes available"13, as is always the case in Kechiche's cinema, all centred on "social classes as regulators of an order that is difficult to negotiate; [...] and on the tranches de vie [...] never understood as mere sections of everyday life, but rather as emblematic segments of learning paths that do not produce evolutions" ${ }^{\text {"14. }}$

\section{The faces of today's young people}

In case of both movies critics recognize the crucial importance of the faces of the protagonists and the way they are filmed. In Jeune Femme, for example, Paula's existential instability and continuous wandering between one niche and another in society, without ever managing to integrate, are symbolically represented by recurrent close-ups of the girl, made with the handheld camera technique, in which her figure is clearly separated from the background, often highlighting her two-tone eyes. In fact, the commentators emphasize how Paula "is almost always shot alone" 15 , precisely to underline her difficulty in becoming integrated with her surroundings, as can be seen in Fig. 1. It has been pointed out that Sérraille directs her film, "centring the camera on the protagonist and accentuating her discomfort and perplexity through serial jump cuts, sequences with a handheld camera" 16 , which reach particular expressivity when they direct the spectator's

12 Carlo Cerofolini, http://icinemaniaci.blogspot.com/2018/04/Montparnasse-femminilesingolare.html (last accessed 25 August 2020).

13 Goffredo Fofi, www.foglianuova.wordpress.com/2013/10/27/goffredo-fofi-la-vita-di-Adèle/ (last accessed 20 February 2017).

14 Michele Marangi, www.lindiceonline.com/l-indice/sommario/dicembre-2013/ (last accessed 20 February 2017).

15 Linda Magnoni, www.cineforum.it/recensione/Montparnasse-Femminile-singolare (last accessed 25 February 2020).

16 Rudi Capra, www.ondacinema.it/film/recensione/montparnasse-femminile-singolare.html (last accessed 25 February 2020). 
attention on Paula's gaze, characterized by the detail of her "bipolar eyes', mirror of an equally bipolar and restless soul"17 (also seen in Fig. 1). It is this characteristic of the face of the protagonist of Jeune Femme - which is obviously constructed to communicate something, given that the eyes of the actress who plays the part are actually brown - that symbolically represents her "wandering" spirit, her perpetual movement among very different places and people. Since the girl's story ends with her choice not to settle down in any of the social contexts in which we have seen her operating, but to continue to seek her own place in the world, critics cannot help but observe that the film ends with a close-up of her face (the third image in Fig. 1), which has been linked to the overall narrative structure of her story: "[...] it will be the viewers who judge whether Paula's future will be seen with brown or blue eyes" 18 .

It is indeed this state of uncertainty, this continuous wandering - which also causes her injuries, as when she cuts her forehead by slamming it against the door that is closed in her face at the beginning of her story, or when she undergoes an abortion at the end - that makes the protagonist of Jeune Femme such a realistic and contemporary character, as underlined by those who say that her existential path is definitely that of one who "finally sees and perceives the world with the eyes and body of a woman, a real woman, who is not afraid to be what she feels herself to be" ${ }^{\prime 19}$. As pointed out at the beginning of the article, this makes several commentators say that Paula and her face could represent a "matrix" of the faces of many young people today.
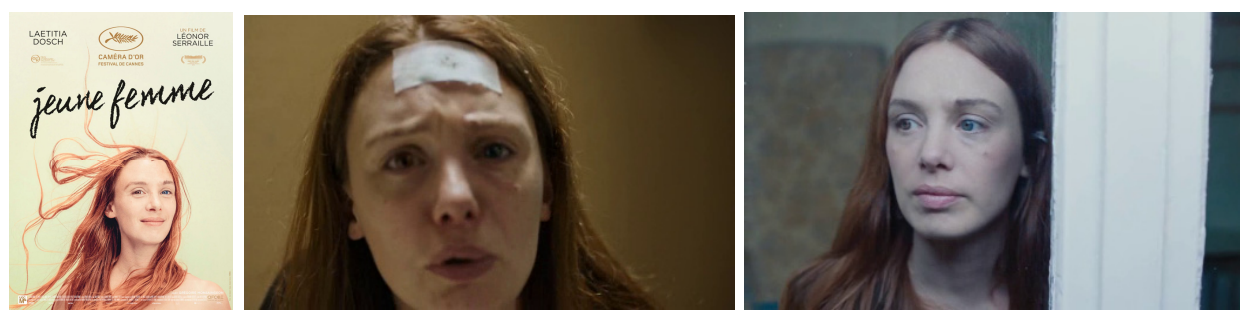

Figure 1.The face of Paula in the movie poster and in some scenes

17 Linda Magnoni, www.cineforum.it/recensione/Montparnasse-Femminile-singolare (last accessed 25 February 2020).

18 Rolando Cisternino, www.anonimacinefili.it/2018/10/03/montparnasse-femminile-singolare (last accessed 25 February 2020).

19 Rolando Cisternino, www.anonimacinefili.it/2018/10/03/montparnasse-femminile-singolare (last accessed 25 February 2020). 
Similar reflections are formulated by the reviewers of La vie d'Adèle: Chapitres $1 \& 2$, which in turn underline the importance of the emphasis placed by the director on the many close-ups of the protagonist of his film, which keep her character separate from the context in which she lives (as can be seen in some of the images in Fig. 2), despite the fact that this very context plays a decisive role in directing the results of the girl's story. This opinion is expressed, for example, by those commentators who consider exalting Kechiche's expertise "in depicting the details of the faces and bodies, in dwelling on the close-ups, and then enlarging the shots to other subjects, where strictly necessary, only when the others become an attraction for Adèle's gaze" 20 , for "there is nothing beyond what the young girl knows and experiences" 21 : "more light, more details enter the field of vision, but things in the background also become blurred"22.
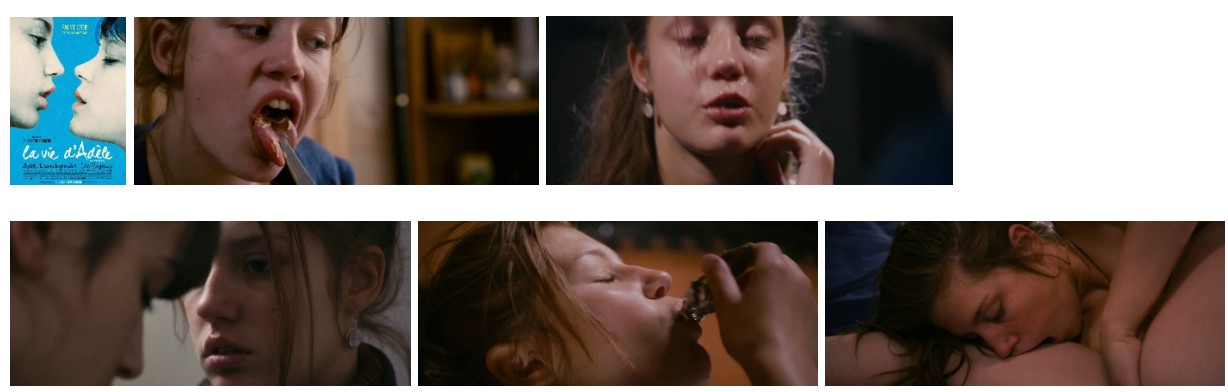

Figure 2. The face of Adèle on the movie poster and in some scenes.

In this very personal exploration of the world and the search for something that gives a definitive meaning to her existence, the images of Adèle's body and face become again fundamental: "since everything is a body, special attention is given to how much the epidermis is animated by the desire for and contact with others" 23 ; "the camera, rarely placed far away from the characters' faces, is a seismograph with an immediate and icastic sensitivity; every change of mood is detected in real time",

20 Giuseppe Gangi, www.ondacinema.it/film/recensione/vita_Adèle.html (last accessed 20 February 2017)

21 Ilaria De Pascalis, www.alfabeta2.it/2013/10/31/il-tempo-intenso-del-desiderio/ (last accessed 20 February 2017).

22 Veronica Vituzzi, www.doppiozero.com/materiali/odeon/kechiche-la-vita-di-Adèle (last accessed 20 February 2017).

23 Veronica Vituzzi, www.doppiozero.com/materiali/odeon/kechiche-la-vita-di-Adèle (last accessed 20 February 2017). 
the filmmaker catching it at the exact moment it manifests itself. The protagonist of the film "is constantly filmed with close-ups or details that exalt her overflowing physicality, her humoural fluids from tears to mucus, the sense of a warm and deep instinctuality" 24 . In particular, her wandering among the different recesses in society and the people who inhabit them is symbolized by her mouth, as can be seen again in Fig. 2: "Adèle is voracious, as suggested by Kechiche's constant return to her lips as she sleeps, eats: lips stretched out, greedy, almost distinct from the rest of her body, as if they lived their own lives and dragged the protagonist forward against her will. Things make sense only through sense" 25 . After the two-tone eyes and the swollen epidermis on Paula's forehead in Jeune Femme, the sensory organs of the face of the main character in La vie d'Adèle: Chapitres 1 \& 2 once again become the most representative element of the existential searching of today's young people, carried out almost gropingly, empirically, by trying everything out on themselves.

\section{Sociosemiotics and the meaning of certain faces}

The reader who has had the patience to follow me so far might have wondered why I decided to work on two films that were similar in many ways, and interpreted more or less in the same way by reviewers. The reason is that, in doing so, I wanted to show how the cultural models that are at the centre of interest in this article work, paving the way for a reflection on the kind of sociosemiotics I wish to discuss.

The cultural models underlying the audio-visual products circulating in the media can be defined as the matrixes of "recurring discursive configurations, governed by precise narrative structures, which hold together entire encyclopaedias of signs" (Santangelo 2012: 120). In practice, we become aware of their existence when, following a working method similar to that of Propp on the morphology of the folk tale (Propp 1928), we understand that there is a common constructive logic behind apparently different contents that is made up of the recurrence of certain signs and narrative structures, as is shown in Fig. 3.

24 Michele Marangi, www.lindiceonline.com/l-indice/sommario/dicembre-2013/ (last accessed 20 February 2017).

25 Veronica Vituzzi, www.doppiozero.com/materiali/odeon/kechiche-la-vita-di-Adèle (last accessed 20 February 2017). 


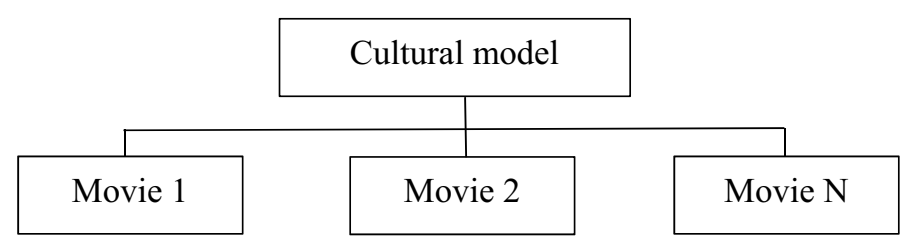

Figure 3. The matrix of different films.

This immediately makes us reflect on the relationship of such contents with the socio-cultural context in which they are produced, as Propp himself thought in his work on the historical roots of the unitary compositional scheme of Russian fairy tales (Propp 1946). Thus, this article is based on the idea that by identifying the similarities between two films, such as La vie d'Adèle: Chapitres $1 \& 2$ and Jeune femme, which do not refer to each other, yet seem clearly connected; it can be assumed that their close relationship is not determined by chance, but by the fact that both derive from a certain model of common thinking about who are today's young people, how they try to find meaning in contemporary society, and how their stories should be told.

This hypothesis can be empirically substantiated with further evidence. Reviews of the films can be used, which are, after all, interpretations of them provided by individuals who belong to the same cultural context. In fact, the other idea on which the method of this article is based is that the cultural models that give rise to the audio-visual products circulating in the media are a sort of communication codes that allow those who make them share their thoughts with the audience who use the same logic in order to recognize the meaning of what they are told. The cultural models, therefore, are also a certain kind of pertinence principles (Prieto 1975), which guide the recipients of cinematographic works within them, allowing them to select and emphasize those content items that in their view determine the meaning of films more than others. What the reviewers find significant in the films, if repeatedly recognized as relevant by many of them, can be employed as a useful guide to identify those recurring discursive configurations that are the most obvious manifestation of the cultural models they find in the films themselves. Otherwise, as is shown in Fig. 4, reviews can serve as empirical confirmation of the interpretations of semiologists in their analysis of film works, indicating that the cultural models they identify are the same as those used by a certain category of their recipients to assign meaning to them. 


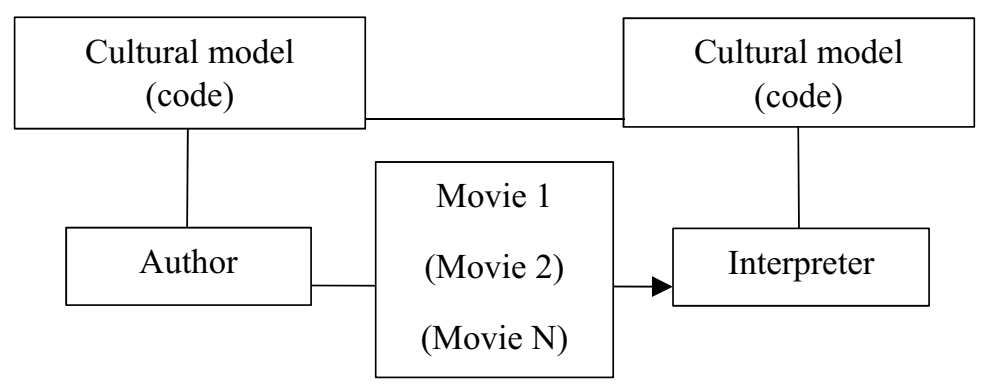

Figure 4. Cultural models as tools for encoding and decoding films.

The roots of this way of conceiving sociosemiotics date back to Saussure's thinking. In fact, a semiotics understood as a social science of signification should try to reconstruct the principles of the functioning of langue (Saussure 2001[1922]: 23) or, to put it more simply, of the code - which gives rise to the communicative exchanges that take place between people in a given context. Only in this way is it possible to pursue the objective of describing the meaning the semiologists' objects of investigation assume not so much in their own eyes, but in those of the other interpreters, in the society in which these objects circulate and are used. The langue is the instrument through which different subjects who wish to express the same concept, even in the idiosyncrasy of their personal acts of parole (Saussure 2001[1922]: 23), craft messages that are similar in some ways. Yet at the same time the langue is the medium used by their recipients, when the latter have to recognize that what is communicated to them is not simply the result of a purely individual choice or behaviour, but the attempt to reproduce a model with a collective value.

This appears clear already in Saussure's (2001[1922]: 145) famous example about the role of language in allowing each of us to write a letter ' $\mathrm{T}$ ' on a sheet of paper in our own handwriting in the reasonable hope of being understood or, to the contrary, about how language itself allows us to understand that the infinite ways in which we can find the same letter written, depending on who penned it, are to be traced back to the same meaning. This is also what happens with the cultural models I am discussing in this article: the directors of La vie d'Adèle: Chapitres 1 \& 2 and Jeune femme use them, metaphorically, to create their own personal versions of the letter ' $\mathrm{T}$ ' of the code for reading the existential experience of today's young people, and Italian film critics use them to decode the messages addressed to them.

Of course, conceiving of culture as a language or as a unitary code is problematic (Volli 2010) and this is not my intention, but empirical work of the type I am presenting here shows that within culture itself there are indeed common 
matrixes of the discourses that people perform about specific issues. To describe these matrixes it is necessary to focus on their narrative structures and on the signs that are articulated within them. In both cases, as Ferraro (2001) shows, it is important to return to the method used by Lévi-Strauss in his analyses of myths all over the world, once again reconnecting to Saussure. That is, as far as signs are concerned, it is necessary to identify in the material discourses to which cultural models give rise, a series of recurring elements which, although apparently dissimilar, are united by the fact that they are made up of a number of common significant characteristics, which produce the same meanings (Saussure 2001[1922]: $84-85)^{26}$. In the same way, as far as narrative structures are concerned, some regular strategies of articulation of these signs must be highlighted which, once identified under the surface of contents that seem to be different, can be recognized as significant structures that convey the same meanings.

In the light of the previous paragraphs, in La vie d'Adèle: Chapitres 1 \& 2 and in Jeune femme, the most relevant signs among those used in these works to construct and interpret the discourses on young people today are those of separation, movement, reliance on the senses, pleasure and, above all, suffering. The two films, in fact, are full of images of the two protagonists framed in such a way that their figures are visually separated from the background of the contexts in which they live, just as there are numerous shots such as those of Adèle on the sidelines of the worldly occasions when Emma socializes with her friends in chic art circles, or others in which Paula is seen in her small attic in the same building in which her landlady and employer occupies the main floors. However, as we know, the two girls move between social environments in search of a place where to find a meaning to their existence and the cameras follow them with handheld mobile shots so as to communicate the idea of dynamism and, at the same time, the precariousness that all this moving, all this research entails. By keeping close to the protagonists, looking at their faces and bodies for signs that, in real time, show what they feel in their attempts to give meaning to their lives, the directors of La vie d'Adèle: Chapitres $1 \& 2$ and Jeune femme end up focusing on their sensory organs and on how their skin, eyes, noses and mouths react to everything in this sort of encounter/clash with reality. In some brief moments of their stories, Adèle and Paula feel pleasure - the Sapphic sex sequences in Kechiche's film are particularly famous in this regard, as are those showing the protagonist enjoying pasta with sauce and oysters, the foodstuffs that symbolize the two different social contexts from which she and Emma come -, but most of the time the two girls suffer, cry, hurt, because not finding their place in the world is painful.

26 Of course, Saussure talks about 'signifiers' and 'signifieds' of signs. 
All these signs which are depicted in the faces of the main characters of the films I am analysing here, and recognized by film critics as fundamental for the reading of the faces of today's young people, symbolically recall the common narrative structure of La vie d'Adèle: Chapitres $1 \& 2$ and Jeune femme, which they literally resemble, embodying its different facets, as can be seen in Fig. 5 .

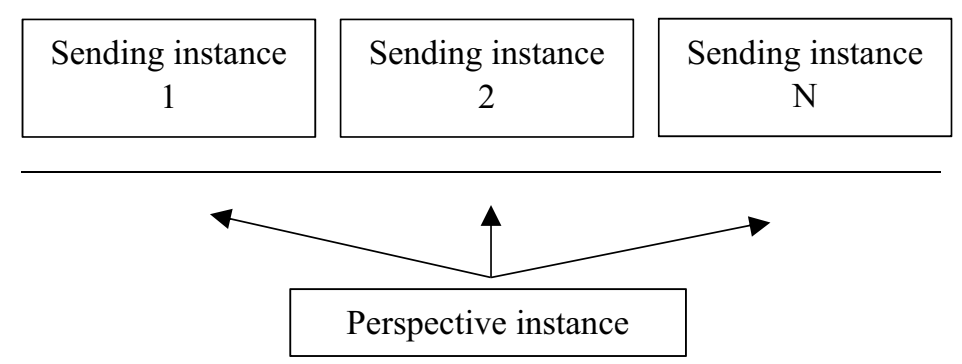

Figure 5. The narrative structure of the two films.

In order to understand the scheme in Fig. 5, it is necessary to point out that, according to Ferraro (2015: 71-100), the architecture of stories which, like those of the two films in question, mainly talk about the identity of their characters, is based on the relationship between a perspective instance and a sending instance. The former has to do with the sphere of the individual, his or her values, his or her perspective on things, and is embodied by the protagonist of the events narrated. The latter, on the other hand, concerns the world outside the protagonists themselves and can be represented by the laws or conventions of the society in which they live, or by another character's way of seeing things, a place, a machine or anything that, focusing on its own values, could or would like to impose a certain destiny on them. The meaning of the narratives that are based on these two instances depends on the relationship that is established between them, a relationship that, after all, has to do with the values these kinds of stories become bearers of as noted by Greimas (1996[1970]: 167-194). The identity of the elements that make up the two instances, whether they are characters, things, environments or eras in which everything is set, depends precisely on these values and on how they relate to one another, whether they resemble or differentiate themselves, become integrated or remain distinct.

As can be seen in Fig. 5, in the case of La vie d'Adèle: Chapitres $1 \& 2$ and Jeune femme, the perspective instance represented by Adèle and Paula, with their values based on extreme freedom, on the desire to be exactly as they want to be - high 
or petit-bourgeois, heterosexual or homosexual, lovers of established artists or of humble workers - clashes with the various "classist" sending instances in society, which would like to define them in one way or another. The reality in which the two girls live is, in fact, made up of strictly separate niches, each hinging on values that, in the end, prove to be different from those of the young girls themselves. Therefore, although they move continuously between the various social contexts in which they try to insert themselves (indicated by the arrows in Fig. 5), also feeling the advantages, the "pleasures" of what it means to be welcomed there for a moment, they end up painfully remaining cut off from these, as if there were a sort of barrier that prevents them from being fully integrated (this is the meaning of the horizontal line in Fig. 5). The faces of Adèle and Paula, like those of the young people they seem to resemble, are the faces of persons who, believing they can affirm their demand for absolute freedom, realize that this, unfortunately, will not allow them to find a place in the world, because the world works in a different way, perpetuating "instances" that are decidedly less open to experimentation and social mobility than the girls and the perspective instances they represent.

What I have just said allows me to address the last question of method that I consider relevant, to reflect on how to determine, in the sociosemiotic paradigm to which I refer, the symbolic meaning of a face. The cultural model from which a face derives takes on its own value by difference, compared to other cultural models whose constituent signs and narrative structure are clearly opposed to its own, according to a logic that leads us to hypothesize that all these matrixes of the various stories circulating in our society are connected in some way: as Saussure states, after all, the numerous different ways of writing the letter ' $\mathrm{T}$ ' are linked by the fact that they are different from the way an 'I' or an 'L' is drawn.

In this sense, as I have already pointed out, it is evident that La vie d'Adèle: Chapitres 1 \& 2 and Jeune femme are characterized by an ending devoid of the typical positive conclusion, which is easily found in those stories in which the perspective and sending instances somehow meet. As can be seen in Fig. 6, this is the case, for example, in the structure of the Russian fairy tales of magic analysed by Propp. Ferraro (2015: 79-85), on the basis of the reflections of Propp, who had highlighted their similarity with the initiation rites of different peoples (Propp 1946), defines them as forms of narrative that speak of the figure of the typical "self-made man", an individual whose values coincide with those of the society in which he lives and who, at the end of his "adventures", proves that he deserves to settle there. In fact, after having faced many tests in an "elsewhere" where different rules and values apply, the protagonist of this kind of storytelling shows that he has been able to fight to realize the rules of the world to which he has always belonged, transfiguring himself and assuming the likeness - and of course also the face - of 
the best of the representatives of this social context, so much so that he often gets to marry "the king's daughter".

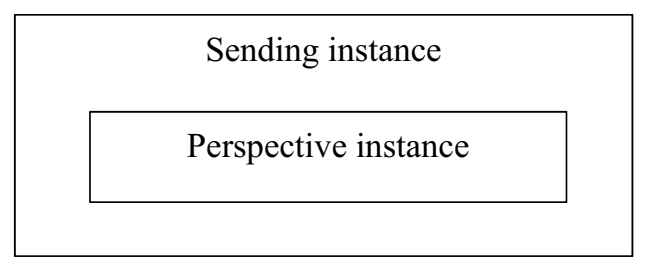

Figure 6. The narrative structure of Russian fairy tales.

However, Russian fairy tales evidently derive from other cultural models of what it means to be young and to become adults. Today we tell ourselves stories like those of Shrek or Avatar, whose narrative structure appears in Fig. 7. The respective protagonists are different from Propp's heroes because, after having elsewhere faced the trials that would allow them to integrate themselves into their respective societies of origin, they realize that these involve an unjust sending instance on which they do not intend to make their identity depend. On the contrary, it is in the other "worlds" that they meet the sending instances whose values allow them to find themselves and for this reason they decide to settle there, transfiguring themselves, but symbolically taking on the appearance of ogres and aliens.

Shrek tells the tale of a princess who is the victim of a curse. She can choose whether to love a prince animated by the worst consumerist values of her (and our) society of belonging, "chaining herself" to its rules and thus becoming a beautiful woman admired by all, or to live forever free to be herself in a swamp with an ogre and other fairy tale characters, while becoming "ugly" and "different" like them in turn. In another case, an American soldier, thanks to a machine developed on planet Earth, "moves" into the body of an alien and into the extra-terrestrial world of planet Pandora to infiltrate its indigenous inhabitants and help his fellow human beings appropriate their precious natural resources. After realizing, however, that the Na'vi society is better than the capitalist society from which he comes, because it respects nature and promotes brotherhood among all living beings, he decides to betray his origins and defend the extra-terrestrials, ending up abandoning his human body forever. 


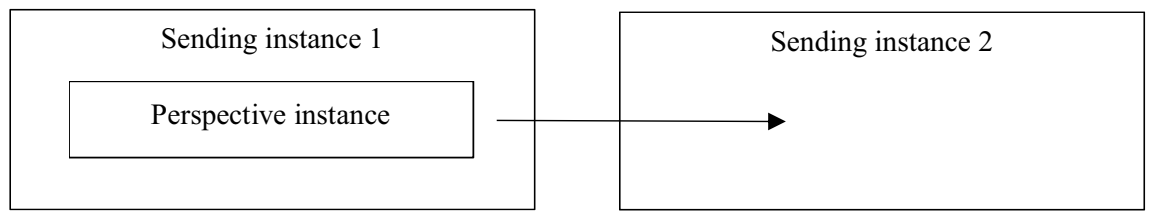

Figure 7. The narrative structure of Shrek and Avatar.

Evidently, Shrek and Avatar derive from a cultural model that overturns that of the fairy tales studied by Propp. If we compare the stories and faces of the characters of these films, and if we juxtapose them with those of Adèle in La vie d'Adèle: Chapitres $1 \& 2$ and Paula in Jeune femme, we realize that their differences still seem to connect them to each other. It could be hypothesized that there is a logic of diachronic transformation, which gradually leads from Propp's unitary compositional scheme to the matrixes of contemporary works, passing from events set in just societies which manage to integrate their young people, offering them a sharable existential horizon, to tales of unjust societies from which young people want to escape, to settle in a better "elsewhere". Today, however, we tell ourselves that this elsewhere no longer exists and that all that has been left to us is wandering around with no precise destination, in search of a meaning and of an identity that we are unlikely to find. This theory would certainly need further analysis, but if it were confirmed, it would reveal once again that we are living in difficult times.

Acknowledgements: This research is part of a project that has received funding from the European Research Council (ERC) under the European Union's Horizon 2020 research and innovation programme (Grant agreement No 819649 - FACETS.

\section{References}

Aristarco, Guido 1951. Storia delle teoriche del film. Torino: Einaudi.

Barthes, Roland 1994[1957]. Miti d’oggi. Torino: Einaudi.

Fabbri, Paolo 1973. Le comunicazioni di massa in Italia: sguardo semiotico e malocchio della sociologia. VS. Quaderni di studi semiotici 5: 57-109.

Casetti, Francesco 1994. Teorie del cinema. 1945-1990. Milano: Bompiani.

Ferraro, Guido 2001. Il linguaggio del mito. Roma: Meltemi.

Ferraro, Guido 2015. Teorie della narrazione. Dai racconti tradizionali allodierno storytelling. Roma: Carocci.

Ferraro, Guido 2017. Senso, forma, nomi e referenza. In: Ferraro, Guido; Santangelo, Antonio (eds.), Narrazione e realtà. Il senso degli eventi. Roma: Aracne, 117-136. 
Gibson, John 2017. Sulla produzione del senso. In: Ferraro, Guido; Santangelo, Antonio (eds.), Narrazione e realtà. Il senso degli eventi. Roma: Aracne, 97-116.

Greimas, Algirdas J. 1996[1970]. Del senso. Milano: Bompiani.

Landowski, Eric 1989. La société réfléchie. Paris: Éditions du Seuil.

Lévi-Strauss, Claude 1964. Anthropologie structurale. Paris: Librairie Plon.

Lukács, Georg 1963. Ästhetik I. Die Eigenart des Ästhetischen. Berlin-Spandau: Hermann Lutherhand.

Marrone, Gianfranco 2001. Corpi sociali. Processi comunicativi e semiotica del testo. Torino: Einaudi.

Prieto, Luis 1975. Pertinence et pratique. Paris: Minuit.

Propp, Vladimir J. 1928. Morfologiya skazki. [The Morphology of the Folktale.] St. Petersburg: Academia.

Propp, Vladimir J. 1946. Istoricheskie korni volshebnoj skazki. [The Historical Roots of the Fairy Tale.] St. Petersburg: Izdatel'stvo leningradskogo gosudarstvennogo universiteta. Rastier, Francois 1986. Impression référentielle. In: Greimas, Algirdas; Courtés, Joseph (eds.), Sémiotique. Dictionnaire raisonné de la théorie du langage. Paris: Hachette.

Santangelo, Antonio 2012. Sociosemiotica dellaudiovisivo. Roma: Aracne.

Santangelo, Antonio 2017. Fuori dal testo cè salvezza. Il senso del film La vita di Adèle. In:

Ferraro, Guido; Santangelo, Antonio (eds.), I sensi del testo. Percorsi interpretativi tra la superficie e il profondo. Roma: Aracne, 41-68.

Santangelo, Antonio 2021. Volti simbolici. Per una teoria sociosemiotica del volto. Lexia 37/38: 503-520.

Saussure, Ferdinand de 2001[1922] Corso di linguistica generale. Roma: Laterza. Volli, Ugo 2010. Al di là delle culture. Le strategie della memoria. Lexia 5/6: 27-40.

\section{Filmography}

Adamson, Andrew; Jenson, Vicky 2001. Shrek. Glendale: Dreamworks Animation. Cameron, James 2009. Avatar. Los Angeles: Twentieth Century-Fox. Kechiche, Abdellatif 2013. La vie d'Adèle: Chapitres 1 \& 2. Paris: Wild Bunch.

Sérraille, Léonor 2017. Jeune femme. Paris: Blue Monday Productions.

\section{Культурно значимые символические лица: социосемиотика лиц в фильмах}

Время от времени при просмотре фильмов мы сталкиваемся с лицами, которым присваиваем особую ценность, так как они отражают важные культурные модели, придающие смысл нашему мироощущению. В качестве примеров я рассматриваю лица главных героев двух недавних фильмов, «Жизнь Адель» Абделлатифа Кечиче (2013) и «Молодая женщина» Леонора Серрейля (2017), и сравниваю их с лицами главных героев некоторых более старых фильмов, таких как «Шрек» Эндрю Адамсона и Вики Дженсон (2001) и «Аватар» Джеймса Кэмерона (2009). Я 
утверждаю, что способ изображения лица похож на повествовательную структуру истории соответствующего персонажа, и что знаки и повествовательные структуры, используемые для построения дискурсов о мире в этих фильмах, аналогичны структурам двух важных культурных моделей - что значит быть молодыми мужчинами и женщинами в наше время. Эти культурные модели различны, но взаимосвязаны, и я полагаю, что наиболее значимые лица в кино меняются из-за трансформации эти культурных моделей. Социосемиотический метод, основанный на структуралистском подходе к культуре, может помочь идентифицировать наиболее значимые в культурном отношении символические лица на экране и в других местах.

\section{Kultuuriliselt tähenduslikud sümboolsed näod: nägude sotsiosemiootika filmides}

Filme vaadates kohtame tihti nägusid, milles tunneme ära märgatava väärtuse, sest need esindavad olulisi kultuurilisi mudeleid, mida me kasutame oma maailmakogemusele tähenduse omistamisel. Näitena käsitlen peategelaste nägusid kahes hiljuti valminud filmis: Abdellatif Kechiche’i linateoses "La vie d'Adèle. Chapitres 1 \& 2" (2013) and Léonor Sérraille' filmis "Jeune femme" (2017), võrreldes neid peategelaste nägudega sellistes vanemates filmides nagu Andrew Adamsoni ja Vicky Jensoni "Shrek" (2001) ning James Cameroni "Avatar" (2009). Väidan, et see, kuidas nägusid kujutatakse, sarnaneb filmitegelaste lugude narratiivse struktuuriga, ja et märgid ning narratiivsed struktruurid, mida nendes filmides kasutatakse maailma puudutavate diskursuste konstrueerimisel, sarnanevad ühtaegu kahele olulise kultuurimudeliga, mis käsitlevad seda, kuidas olla tänapäeval noor naine või mees. Et need kultuurimudelid on erinevad, kuid omavahel seotud, väidan, et kõige tähendusrikkamad näod kinos muutuvad tänu nende kultuurimudelite muutumisele, millest nad pärinevad, ja strukturalistlikul kultuurivaatel põhinev sotsiosemiootiline meetod võib aidata kindlaks teha kultuuriliselt kõige olulisemaid sümbooseid nägusid nii ekraanil kui ka mujal. 